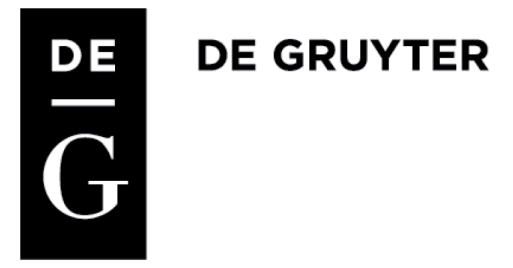

Tomasz Trawiński (Regional Police Commander in Poznań)

\title{
NATIONAL ACADEMIC CONFERENCE - FINANCIAL CRIME IN POLAND
}

This is a speech by superintendent Tomasz Trawinski, the regional police commander in Poznan, who opened the first of the series of conferences devoted to the history of financial crime in Poland. The present threat of escalating financial crime is not only the concern of the agencies established for fighting this abnormality, but also of other institutions which can potentially be of help in fulfilling this task. In this field, the Polish police is open to new forms of cooperation and one of them is the collaboration with academic and scientific centers.

Keywords: Police, financial crime, cooperation, university.

doi:10.1515/sho-2016-0001

\section{WELCOMING ADDRESS}

When Iheard about the initiative by the Faculty of History and Institute of History of the Adam Mickiewicz University concerning the organization of a conference on broadly understood financial crime, I approved. The Greater Poland police has been cooperating with Poznań universities for quite some time in the field of various academic, research and teaching initiatives related to public safety. In the times when economic crime flourishes - very often crime of an international nature - every action improving our efficiency deserves approval. Therefore, I accepted the invitation to hold honorary patronage of this event, assuming the full responsibility it entails. What is noteworthy is the fact that due to its scope and importance for Poland, other forces are also committed to fighting 
this type of crime. These forces include: the Internal Security Agency, the Central Anti-Corruption Bureau, Customs Service and Treasury Intelligence.

\section{POLICE TASKS}

Police in Greater Poland and the abovementioned forces undertake numerous operational, investigative and preventive actions which aim at detecting crimes and protecting potential victims. In order to efficiently execute these tasks, we need cooperation, mainly with institutions, academic units, associations, and citizens. Criminology specialists claim that what makes financial crime in Poland distinctive is the fact that most citizens accept it or even approve of it. Financial criminals are often simply considered resourceful. What lies behind this reasoning is history, especially the history of the times we will discuss today, namely the Polish People's Republic era, but also the periods of occupation and partitions, when the authorities were either imposed by a third party or simply foreign. Now, Poland is not only an independent, but also a democratic state. Poland is our common good. Now, financial crimes are crimes aimed against the state, which means they are directly or indirectly aimed against all citizens. One example can be tax evasion - depriving the state of the funds due means that less money can be spent on academic activities, investments or social development programs.

\section{POLICE EXPECTATIONS}

Researching financial crime is a task for representatives of many academic disciplines e.g. law, economics, history or sociology. Gathering academics from so many backgrounds can be a problem. However, today, in Poznań, we witness one such attempt. I am sure it will prove successful. I hope that this conference will not be the last one in Poznan devoted to financial crime - that this is only the beginning. Personally, I would like Poznan to become the center of research on this type of crime. I will try, as much as I can as a police commander, to support further initiatives - not only in terms of research, but also of education. The Police and 
the Adam Mickiewicz University have been cooperating for years. Now this cooperation can be extended by adding the issue of financial crime. You, as academics, have the expertise and international contacts which are so important when it comes to researching new methods of committing these crimes. Me, I have officers in the force who are greatly experienced in fighting financial crime and are willing to share this experience.

Thank you for inviting me and letting me speak here in the headquarters of the Poznan Society of Friends of Learning, an organization with nearly 170 years of history. The fact that the Society co-hosts this event is evidence of both the interdisciplinary nature of financial crime (which I have already mentioned) and of the ability of academics to cooperate. I am proud that we can be part of this cooperation.

Tomasz Trawiński - superintendent, regional police commander for Greater Poland Voivodeship in Poznań. In police since 1991. In 2012-2016 deputy commander of Police in Bydgoszcz. He graduated Faculty of Law and Administration at the University of Wrocław, Police Academy in Szczytno and Faculty of Management in Poznań University of Economics and Business. 
